perimental studies are needed to determine the roles of these various movements and sounds during precopulatory behaviour in these species.

\section{Acknowledgments}

Thanks are due to D. W. Whitfield and R. C. Holmberg who produced the oscillograms and to Dr. J. S. Rovner for his helpful comments.

\section{LITERATURE CITED}

Bonnet, P. 1945. Bibliographia Araneorum. Tome I. Les Frères Douladoure. p. 274.
Bristowe, W. S. 1929. The mating habits of spiders, with special reference to the problems surrounding sexual dimorphism. Proc. Zool. Soc. Lond., 309-358.

Chopard, L. 1934. Sur les bruits parduits par certaines araignées. Bull. Zool. Soc. Fr., $59: 132-134$.

Hallander, H. 1967. Courtship display and habitat selection in the wolf spider Pardosa chelata (O. F. Muller). Oikos, $18: 145-150$.

Harrison, J. B. 1969. Acoustic behavior of a wolf spider, Lycosa gulosa. Anim. Behav., $17: 14-16$.

Lahee, F. H. 1904. The calls of spiders. Psyche, $11: 74$.

Rovner, J. S. 1967. Acoustic communication in a lycosid spider (Lycosa rabida Walckenaer). Anim. Behav., $15: 273-281$.

\title{
THE BUTTERFLIES OF MANITOBA'S PROVINCIAL PARKS I: WHITESHELL PROVINCIAL PARK
}

\author{
by John H. Masters, P.O. Box 7511, St. Paul, Minnesota
}

With 675,840 acres, Whiteshell is Manitoba's largest provincial park. Located in extreme southeastern Manitoba, it can be reached by the TransCanada highway No. 1 or Manitoba trunk highway No. 4. The region is typical boreal zone of eastern Manitoba and northern Ontario. It is situated on Precambrian or Canadian Shield where lakes, rivers, acid bogs and rock outcroppings are all numerous. Birch and aspen forests cover most of the region, but these are replaced by jack pine on rock outcroppings or sandy areas, by black spruce in bogs, and by larch in swampy areas.

The butterflies of Whiteshell have received some attention in the past. George Shirley Brooks, who published a check-list of the butterflies of Manitoba (1942), collected at Seven Sisters Falls before the Provincial Park was formed, and recorded several species from here. Charles D. Bird spent the summers of 1954 and 1955 at Red Rock Lake and published a list (1956) of 40 species of butterflies he collected there. Between 1966 and 1971, I made six collecting trips to Whiteshell as part of field work on a Manitoba Lepidoptera project. My collecting has added several species to Bird's list and in addition, I am adding adult flight date and habitat data that were missing from the previous reports. Skippers (Hesperiidae) have not been included in this study.

\section{Species List \\ Swallowtail Butterflies: \\ PAPILIONIDAE}

TIGER SWALLOWTAIL Papilio glaucus canadensis Rothschild \& Jordan A common and conspicuous species of roadsides and deciduous forests. Adults in mid-June to early July.

\section{Whites and Sulphurs:}

\section{PIERIDAE}

NORTHERN WHITE Pieris napi oleracea Harris One of very few double-brooded species in this region. 'The first brood emerges in mid-May and may be taken until mid-June, the second brood is on the wing in August. A woodland species.

CABBAGE BUTTERFLY Pieris rapae (Linnaeus) This is an ubiquitous species originating from Europe and reported from Whiteshell by Bird. The butterflies would not be expected to penetrate any of the forested areas and are more to be expected around gardens or human habitats. They would be expected to fly throughout the summer period.

ORANGE SULPHUR Colias eurytheme eurytheme Boisduval $\mathrm{T}$ h is species is not especially common at Whiteshell. It is to be found in late 
summer (it may not overwinter here), principally along roadsides.

COMMON SULHPUR Colias philodice philodice Godart This, like $C$. eurytheme, is principally a roadside butterfly at Whiteshell. Although it is somewhat scarce, it may be taken from June until September.

BLUEBERRY SULPHUR Colias interior interior Scudder L o c a lly common at the edges of bogs or other areas where blueberries grow from late June until the end of July.

GIANT SULPHUR Colias gigantea Strecker This species is not yet recorded from Whiteshell, but is likely to occur here. The first records from eastern Manitoba were provided by Masters (1970). The species should be looked for in bogs from late July to early August.

LARGE MARBLE Euchloe ausonides ssp. Lucas This species was first recorded from Whiteshell by Bird. The eastern Manitoba population is quite distinct from $E$. ausonides mayi Chermock \& Chermock of western Manitoba, to which it has been referred in the past. Adults are on the wing in early June and they are most abundant in areas where jack pine occurs.

\section{Monarchs:}

\section{DANAIDAE}

MONARCH Danaus plexippus plexippus (Linnaeus) $\mathrm{Th}$ is well known migrant butterfly seldom penetrates into the Whiteshell region, but in some years it may be quite common here. Adults are most likely to be taken in late summer, however, my only example was collected in June.

\section{Satyrs and Wood Nymphs:} SATYRIDAE

PEARLY EYE Lethe anthedon borealis (Clark) Found in deciduous woods from June until early July. Lethe anthedon has been formerly considered as a subspecies of Lethe portlandia (Fabricius). The Whiteshell subspecies, borealis, is quite similar in appearance to the nominate subspecies, but very different in habitat and habits. (Masters, 1971).

EYED BROWN Lethe eurydice eurydice (Johansson) In the Whiteshell region, this species seems to inhabit grassy bogs. Adults can be taken from mid-July until midAugust.

LITTLE WOOD NYMPH Euptychia cymela cymela (Cramer) Recorded from Whiteshell by Bird. This is a species of deciduous woods. Its northern range limit usually corresponds with the northern limit of red oak, which does not quite reach Whiteshell. It should be looked for in late June.

INORNATE RINGLET Coenonympha tullia inornata Edwards Only a few records from Whiteshell. Found on roadsides or grassy areas in woodlands, usually in July.

AMERICAN GRAYLING Cercyonis pegala nephele (Kirby) For some reason, there are no records of this species from Whiteshell although it should occur here. It should be looked for in deciduous woods during July.

SPRUCE EREBIA Erebia disa mancinus Doubleday I took the only Whiteshell examples of Erebia disa in a bog near Brereton Lake on June 29, 1968. This species seems to be associated with bogs that have heavy stands of black spruce and should be sought in the last few days of June or in early July. There is some reason to suspect that it may occur biennially - that is to say, adults only fly every other year.

RED - DISCED EREBIA Erebia discoidalis discoidalis (Kirby) This species is to be found at the edges of open grassy bogs in late May. It is not rare at Whiteshell, but has never been taken in numbers.

MACOUN'S ARCTIC Oeneis macounii (Edwards) This highly prized species was first recorded from Whiteshell by Bird who considered it to be a significant range extension. It is now known to be quite widespread in jack pine areas throughout southeastern Manitoba. It flies in late June and early July in Manitoba; Pat Conway and I found it quite common at Whiteshell on June 29, 1968. It is biennial and in eastern Manitoba 
it flies only in even-numbered years; in western Manitoba it flies only in odd-numbered years. Detaileá notes on its habitat and habits at Riding Mountain, Manitoba are provided by Masters and Sorensen (1968).

BOG ARCTIC Oeneis jutta ascerta Masters \& Sorensen This is a bog species with an adult flight in late June to early July. Like Oeneis macounii it has a biennial flight, but flies in odd-numbered years, alternating with O. macounii, in eastern Manitoba. Interestingly, however, two specimens were taken by me, in abeyance of the biennial flight, near Brereton Lake in late June 1968.

\section{Brush-footed Butterflies:} NYMPHALIDAE

WHITE ADMIRAL Limenitis arthemis arthemis (Drury) A conspicuous and common butterfly throughout the Park. Found from the last week of June through July along roadsides and in deciduous forest areas. Specimens from Whiteshell show some signs of intergradation to ssp. rubrofasciata (Barnes \& McDunnough), but I prefer to reserve that name for populations of western Manitoba and westward.

V I C E R O Y Limenitis archippus archippus (Cramer) Recorded from Whiteshell by Bird, I have not seen it here. It would be expected to occur in July and August in marshy areas where willow grows.

RED ADMIRAL Vanessa atalanta $r u b r i a$ (Fruhstorfer) A roadside species that is rather scarce at Whiteshell. I have one record from June 1966.

HUNTER'S BUTTERFLY Cynthia virginiensis (Drury) Recorded from Whiteshell by Bird. Possibly occurring here as a migrant only.

PAINTED LADY Cynthia cardui (Linnaeus) A migrant species at Whiteshell, very common here in 1967 , but not seen in other years.

COMPTON'S TORTOISE SHELL Nymphalis j-album j-album (Boisduval \& LeConte) A common species along roadsides in August and early September, $j$-album presumably overwinters as an adult and may again be taken in early spring.

MOURNING CLOAK Nymphalis a $n$ tiop a antiopa (Linnaeus) Not nearly so abundant as Nymphalis $j$-album at Whiteshell, but occurring at the same time and places.

MILBERT'S TORTOISE SHELL Nymphalis milberti milberti (Godart) A somewhat scarce but widespread species, milberti occurs in all habitats but seems to prefer wet open fields. There are at least two broods a season and they are somewhat irregular in occurrence from year to year, thus adults may be observed sporadically from May to September.

SATYR ANGLE-WING Polygonia satyrus neomarsyas dos Passos. This is the scarcest of the three Polygonia that are known to occur at Whiteshell. It is found in company of the other two species, along roadsides in August or September, but does not penetrate deeply into wooded areas as the other two do.

GREEN COMMA Polygonia faunus faunus (Edwards) This is the most frequently encountered species of Polygonia at Whiteshell. It overwinters as hibernating adult butterflies, as do the other Polygonia, and tattered specimens are often taken as late as mid-June. I have often wondered whether they all overwinter as adults or whether some individuals overwinter as pupa and then emerge quite early in the spring. Fresh adults are seen in August and September.

GRAY COMMA Polygonia progne (Cramer) This species is either double-brooded or partially doublebrooded here. Fresh examples can be found in June and again in late August and September. It is a woodland species but can be most readily observed along roadsides and trails.

P E A R L CRESCENT Phyciodes tharos (Drury) ssp. A common roadside butterfly, having at least two annual broods with adults flying almost continually from early June until late August.

TAWNY CRESCENT Phyciodes batesii (Reakirt) This is a sibling species to Phyciodes tharos. Most 
Manitoba lepidopterists have, in the past, failed to distinguish between the two and, as a result, there are virtually no records of batesii for the province. Phyciodes batesii, unlike tharos, is single-brooded with peak flight in early July. It is found together with tharos most frequently at mud-puddle congregations, but is not nearly as common and apparently is much more restrictive in its habitat requirement.

SILVERY CRESCENT Chlosyne nycteis reversa Chermock \& Chermock Recorded from Whiteshell by Bird; I have not taken it here. The proper adult flight dates should be late June into mid-July and the habitat should be wet fields and marshy areas.

SILVER-BORDERED F R I T I LL A R Y Boloria selene atrocostalis (Huard) In this area, Boloria selene is restricted in habitat to wet marshy areas and the marshy borders of bogs. There are apparently two annual broods with peak adult flights in mid-June and mid-August.

MEADOW FRITILLARY Boloria bellona toddi (Holland) This species is more widespread in occurrence than the other Boloria and is to be found in meadows and along roadsides. It is the only Boloria to be found in dry upland meadows at Whiteshell. It is at least partially double-brooded with adults in June and again in late July.

F R E I J A FRITILLARY Boloria freija Thunberg ssp. As of yet I have no records of Boloria freija for Whiteshell or southeast Manitoba at all. The species is found on the Manitoba Escarpment and throughout northern Manitoba, thence southeastward to Carlton County, Minnesota and it is to be expected in Whiteshell. Boloria freija inhabits bogs, preferring the more open ones, and adults would be expected in late May to early June.

PURPLE LESSER FRITILLARY Boloria titania grandis (Barnes \& McDunnough) This choice fritillary is not uncommon at Whiteshell in early August. It apparently is a bog obligate in this part of its range, but is an avid visitor at flowers. There are no flowers in bloom in Whiteshell bogs in August and it is probably because of this that individuals are sometimes taken at flowers some distance away from bogs.

BOG FRITILLARY Boloria eunomia dawsoni (Barnes \& McDunnough) This species is a bog obligate and has been reputed to have a very short annual flight. Although it may be quite common locally, it is generally rare in collections and published records of its occurrence are sparse. The only records for southeastern Manitoba, and for Whiteshell, are a short series of about six males taken by the author and Pat Conway in a bog just west of the park boundary at Rennie on June 29, 1968.

ATLANTIS FRITILLARY Speyeria atlantis atlantis ( $\mathrm{E} \mathrm{d}$ wa $\mathrm{rds}$ ) This is the most common Speyeria at Whiteshell. It is a Canadian Zone woodland species but strays throughout the area, being found at flowers along roadsides, in fields, forests, marshes and bogs alike. It is singlebrooded with adults first being on the wing in mid-June, but the emergence period is prolonged and fairly fresh examples can still be found in early August.

GR E A T SPANGLED FRITILLARY Speyeria cybele Fabricius ssp. This is the scarcest Speyeria at Whiteshell. It was recorded here by Bird, but I have not taken it. Southeastern Manitoba examples of Speyeria cybele are difficult to place as to subspecies; they show intergradation between nominate cybele, krautwurmi ( $\mathrm{Holl} \mathrm{and}$ ) and pseudocarpenteri (Chermock \& Chermock).

APHRODITE FRITILLARY Speyeria aphrodite winni (Gunder) In the Whiteshell populations, Speyeria aphrodite and atlantis are almost indistinguishable, Aphrodite taking on a close resemblance to atlantis. The population is quite distinct in appearance from the populations of $S$. $a$. mayae of western Maniotba and from those of nominate $S$. a. aphrodite of areas to the southeast of Manitoba. The assignment of them to winni is 
only tentative, however. Speyeria aphrodite is not nearly as common as Speyeria atlantis at Whiteshell. The two occur together, although the emergence period for aphrodite may be a little later.

\section{VARIEGATED FRIT ILLARY} Euptoieta claudia claudia (Cramer) This species is not a permanent resident at Whiteshell, but migrates here sporadically and in small numbers. It was recorded from Whiteshell by Bird and I have taken it here twice. One of the specimens that I took was found in a bog during June 1966.

\section{Hairstreaks and Blues:}

\section{LYCAENIDAE}

BOG ELFIN Callophrys (Incisalia) augustinus augustinus (Westwood) Incisalia augustinus is confined, almost exclusively, to bog habitats in Manitaba, although it is more widespread in occurrence elsewhere. At Whiteshell it is ubiquitous to all bogs from mid-May until mid-June.

PINE ELFIN Incisalia niphon clarki Freeman Recorded from Whiteshell by Bird. This species should be looked for in jack pine areas during early to mid-June.

CORAL HAIRSTREAK Harkenclenus titus titus (Fabricius) Not uncommon along roadsides in July.

STRIPED HAIRSTREAK Satyrium liparops fletcheri (Michener \& dos Passos) Taken at flowers in forest openings or along roadsides in early August.

ACADIAN HAIRSTREAK Satyrium acadica acadica (E d w a $\mathrm{rd}$ s) Recorded from Whiteshell by Bird. Satyrium acadica is usually associated with the Transition Zone and is not to be expected quite as far north as Whiteshell. It is a species of marshy areas.

HARVESTER Feniseca tarquinius tarquinius (Fabricius) This is a very rare butterfly in Manitoba. Bird recorded one specimen at Whiteshell, June 15, 1954.

DORCAS COPPER Lycaena dorcas dorcas $\mathrm{K}$ i r b y A single-brooded species with adults in early July. I have had the most luck in finding them at the edges of bogs.

BOG COPPER Lycaena epixanthe (Boisduval \& LeConte) ssp. Bird's record of this species for Whiteshell was the first Manitoba record. The species is now known to be widespread in Manitoba bogs. In the past, it has probably been confused with the previous species. It is singlebrooded with adults from mid-July until early August.

N O R T H E R N BLUE Lycaeides argyrognomon (Bergstrasser) ssp. Whiteshell specimens of argyrognomon belong to an as yet unnamed subspecies and not to ssp. scudderii (Edwards) as they are commonly attributed. The species was recorded from Whiteshell by Bird; I have not taken it here. It should be found in mid- to late July. The habitat is seemingly very selective in certain clearings in the forested areas.

GREENISH BLUE Plebejus saepiolus saepiolus (Boisduval) A single-brooded species appearing from mid-June to early July.

Everes comyntas comyntas (Godart) Southeast Manitoba is part of a very limited area where $E$. comyntas and $E$. amyntula occur sympatrically, comyntas being an eastern species and amyntula a western one. They are similar in appearance and previous Manitoba records for one or the other are usually confused. $E$. comyntas is the commoner of the two; it is multiple-brooded and occurs in nearly every habitat throughout the summer.

Everes amyntula albrighti Clench The assignment of eastern Manitoba examples of $E$. amyntula to albrighti is tentative. At Whiteshell, amyntula is single-brooded with an adult flight in the first half of July.

SILVERY B L U E Glaucopsyche lygdamus couperi Grote This is an early species, occurring in deciduous forests in late May and early June.

SPRING AZURE Celastrina argiolus pseudargiolus (Boisduval \& LeConte) A double-brooded species of deciduous forests. Adults in May and again in July. 


\section{Summary}

The 55 species listed for Whiteshell, represent 76 per cent of the 72 species known to occur in southeastern Manitoba. It is quite likely that another five or six will be eventually recorded at Whiteshell. Skippers (Hesperiidae) have not been included in my study. Bird (1956) recorded seven species of skippers for Whiteshell, but there are possibly a dozen species occurring here.

\section{LITERATURE CITED}

Bird, C. D. 1956. A collection of Rhopalocera from the Whiteshell Forest Reserve, Manitoba. Levidonterists' News, 10:107-108.

Brooks, G. S. 1942. A revised checklist of the butterflies of Manitoba. Canadian Entomolorist, $74: 31-36$.

Masters, J. H. 1970. Records of Colias gigantea Strecker (Pieridae) from Southeast Manitoba and? Minnesota. Jour. Research Lenidovtera, \& $[1969]: 129-132$.

Master's, J. H. 1971. A note on Iethe antheron borealis (Satyridae). Jour. Levidopterists" Society, $25: 256-261$.

Masters, J. H., and J. T. Sorensen. 1968. Bionomic notes on the Satyrid butterfly Oeneis macounii at Riding Mountain, Manitoba. Blue Jay, $26: 258-260$.

\title{
A LIST OF BUTTERFLIES TAKEN AT NORTHWEST ANGLE PROVINCIAL FOREST, MANITOBA
}

\author{
by John H. Masters, P.O. Box 7511, St. Paul, Minnesota
}

Manitoba's Northwest Angle Provincial Forest is locater in the extreme southeast corner of the province. It borders Minnesota's Northwest Angle and Buffalo Bay of the Lake of the Woods, but is traversed by a single highway Manitoba's No. 308 which can be taken out of Sprague or East Braintree. The forest reserve is comprised of over 150,000 acres, most of which is in seral forest growth. A tourist court and campgrounds and picnic areas are located at Moose Lake. The entire area is Canadian Zone forest with birch and aspen gradually yielding back to pine and spruce interspersed with large marshy areas and smaller sphagnum bogs.

During the last six years, I have been studying butterfly distribution in Manitoba and have spent three weekends in the Northwest Angle Provincial Forest. Since I now have the butterfly distribution of southeast Manitoba pretty much in hand and expect to concentrate on the northwest and southwest areas during the next two to three years, I don't contemplate any further studies in the Northwest Angle Forest. Since there are no published records of butterflies from here, it seems worthwhile to record those species that I have found.
My collecting was done in July and August of 1969 and August of 1970; thus I have no records of species flying in May and June. In all, 33 species are recorded, this being only slightly over half of the 50 to 60 that are expected here. Whiteshell Provincial Park is directly north of the Northwest Angle Forest and contains almost identical habitats. All but two of the known Northwest Angle species, Polygonia comma and Lycaena helloides, have also been taken at Whiteshell. The remaining 30 species have identical flight periods and habitats at both spots, these having been given in some detail in another paper (Masters, 1972. The butterflies of Manitoba's provincial parks. I. Whiteshell Provincial Park. In Press). The species observed are as follows:

PAPILIONIDAE :

Papilio glaucus canadensis Rothschild \& Jordan.

\section{PIERIDAE :}

Pieris napi oleracea Harris, Pieris rapae (Linnaeus), Colias eurytherne eurytheme Boisduval, Colias philodice philodice Godart, Colias interior interior Scudder.

\section{SATYRIDAE :}

Lethe anthedon borealis (Clark), Lethe eurydice eurydice (Johansson), Cercyonis pegala nephele (Kirby). 